\title{
Silver-Modified Mexican Clinoptilolite-Rich Tuffs With Various Particle Sizes as Antimicrobial Agents Against Escherichia coli
}

\author{
Isaías De la Rosa-Gómez, ${ }^{1,2}$ María Teresa Olguín, ${ }^{1 *}$ and David Alcántara ${ }^{1}$ \\ ${ }^{1}$ Instituto Nacional de Investigaciones Nucleares, Departamento de Química, A.P. 18-1027, Col. Escandón, Delegación Miguel \\ Hidalgo, C.P. 11801, México, D.F., México. \\ ${ }^{2}$ Instituto Tecnológico de Toluca, Av. Tecnológico s/n, Ex-rancho La Virgen, 52140 Metepec, Estado de México, México.
}

\section{Dedicated to Silvia Bulbulian}

Received December 8, 2009; Accepted April 23, 2010

\begin{abstract}
Water disinfection was performed using Mexican clinoptilolite-rich tuffs from Oaxaca and Sonora with different particle sizes exchanged with silver ions. Samples of Escherichia coli (ATCC 8739) suspended in distilled water (wastewater-like) and municipal wastewater containing coliforms (E. coli as a representative microorganisms from the coliform consortium), were treated in this investigation. E. coli is considered an indicator of microbiological contamination of water, so levels of this microorganism after zeolite treatment indicate how well the disinfection process worked. It was found that particle size, the amount of silver in the modified zeolitic rocks, the origin of the zeolitic material and the type of aqueous media containing $E$. coli all play important roles in the wastewater disinfection process.
\end{abstract}

Keywords: Coliform, Antimicrobial agents, Silver, Clinoptilolite.

\section{Introduction}

Elimination of pathogenic microorganisms from water is one of the most important aspects of a water treatment system. Disinfection of water can be achieved using chemical and physical agents such as chlorine and its derivatives, ozone or ultraviolet light [1-6]. Silver or zinc modified natural zeolites have been proposed as water disinfectants [7-10]. A study by Rivera-Garza [11] found that a silver modified clinoptilolite-heulandite-rich tuff releases silver ions into water, causing elimination of coliform microorganisms after a $2 \mathrm{~h}$ treatment. Under these conditions, the silver level in water was $26.2 \mu \mathrm{g} / \mathrm{L}$. Investigations by Burrola-Aguilar [12] and De la Rosa-Gómez [13] evaluated the antibacterial effect of silver-modified natural zeolites using pathogenic bacteria as an indicator of fecal water contamination. In the study by Burrola-Aguilar [12], E. coli suspended in distilled water was treated with silver, copper and zinc modified natural zeolites. Disinfection efficiency was found to be similar upon treatment with both silver and copper modified natural zeolites, however the silver modified natural zeolite showed a significant difference in the time required to reach total disinfection. In the study by De la Rosa-Gómez [13], disinfection of $E$. coli suspended in distilled water and total coliforms from wastewater was performed using silver-modified natural zeolite. Notable differences in disinfection were observed between the westawater-like and the municipal wastewater due to the
Resumen. Se investigó la desinfección del agua utilizando zeolitas naturales mexicanas procedentes de Oaxaca y Sonora, con diferente dimensiones de partícula e intercambiadas con iones plata, frente a Escherichia coli (ATCC 8739) suspendida en agua destilada (llamada como agua similar a la residual) y coliformes totales (considerando a $E$. coli como parte del consorcio microbiano), contenidos en aguas residuales de origen municipal. Se eligió a dicho microorganismo como indicador de contaminación biológica del agua, para llevar a cabo el proceso de desinfección. Se encontró que las dimensiones de la partícula, la cantidad de plata presente en la roca zeolítica modificada, la procedencia del material zeolítico y el medio acuoso en donde se encuentra suspendida $E$. coli, juegan un papel importante sobre el proceso de desinfección.

Palabras clave: Coliformes, agentes antimicrobianos, plata, clinoptilolita.

presence of chloride ions in municipal wastewater. Chloride ions in wastewater are important because they can react with silver ions and precipitate as solid silver chloride, causing a decrease in the microbicidal activity of the silver-modified natural zeolite. Concentrations of silver present after municipal wastewater disinfection are 2 to 3.5 times lower than the amount found after disinfection of the E. coli suspended in distilled water. This difference is probably due to the chemical and physical properties of wastewater such as conductivity, $\mathrm{pH}$, turbidity, ammoniacal nitrogen and chlorides. The typical concentration of chloride ion in wastewater is approximately $40 \mathrm{mg} / \mathrm{L}[14,15]$.

In the previously discussed studies, the effect of particle size on coliform disinfection was not investigated. The aim of this work was evaluation of the bactericidal effect of silver-modified natural zeolites on both a wastewater-like and municipal wastewater with. E. coli as an indicator of microbe polluted water. The effect of origin of the natural Mexican zeolites and zeolite application time on disinfection efficiency were investigated.

\section{Results and Discussion}

\section{Silver-modified clinoptilolite-rich tuffs}

The amount of silver in the modified natural zeolites with different particle sizes was found to be similar in 12,20 , and 30 
mesh particle sizes (around $139 \mathrm{mgAg} / \mathrm{g}$ for the zeolite from Oaxaca and $30 \mathrm{mgAg} / \mathrm{g}$ for the zeolite from Sonora). The higher concentration of silver in the modified natural zeolite from Oaxaca suggests that this zeolite will more efficiently disinfect water in comparison to the silver-modified natural zeolite from Sonora.

\section{Water Disinfection Disinfection of wastewater-like using silver-modified natural zeolites from Oaxaca (ZOAg) and Sonora (ZSAg) with different particle sizes}

Total disinfection of the E. coli suspended in distilled water was reached after 2 hours using ZOAg12, ZOAg20, ZOAg30 and ZSAg12. Similar behavior was observed by Rivera-Garza et al. [16] using silver-modified natural zeolite from Guerrero with grain size of 10 mesh against $E$. coli and $S$. faecalis suspended in distilled water. Application of ZSAg20 or ZSAg30 to a wastewater-like caused the number of viable cells to decrease by $99 \%$ after $6 \mathrm{~h}$ (Tables 1 and 2). ZSAg12 caused more efficient disinfection of waste water-like the (E. coli suspended in distilled water) compared to ZSAg20 and ZSAg30. Significant disinfection of $E$. coli suspended in distilled water was not observed using either sodium-modified natural zeolite from Oaxaca or Sonora with particle sizes of 12, 20 and 30 mesh (ZONa12, ZONa20, ZONa30, ZSNa12, ZSNa20 and ZSNa30) after a $6 \mathrm{~h}$ disinfection time.

\section{Disinfection of municipal wastewater using silver-modified natural zeolites from Oaxaca and Sonora with different particle sizes}

The numbers of viable $E$. coli as a part of microbial consortium of total coliforms from municipal wastewater after different lengths of treatment with sodium- and silver-modified natural zeolites with particle dimension of 12 mesh from Oaxaca and Sonora are listed in Tables 3 and 4, respectively.

Inspection of the data reveals that treatment of wastewater with either ZOAg12 or ZSAg12 for 2 hours decreased the $E$. coli content of the wastewater by $99 \%$ in most cases. The viable cell count of $E$. coli is observed to decrease with increasing disinfection time. The important differences seen in disinfection of water using silver-modified Oaxaca or Sonora zeolites may be due to differences in the $\mathrm{Si} / \mathrm{Al}$ ratio of zeolites from different origins. This ratio is 4.46 for zeolites from Sonora and 5.47 for Oaxacan zeolites [14].

Silver-modified natural zeolites from Oaxaca and Sonora with particle sizes of 20 and 30 mesh similarly disinfected

Table 1. Disinfection of wastewater-like (E. coli suspended in distilled water) by silver-modified natural zeolite from Sonora with a 20 mesh particle size.

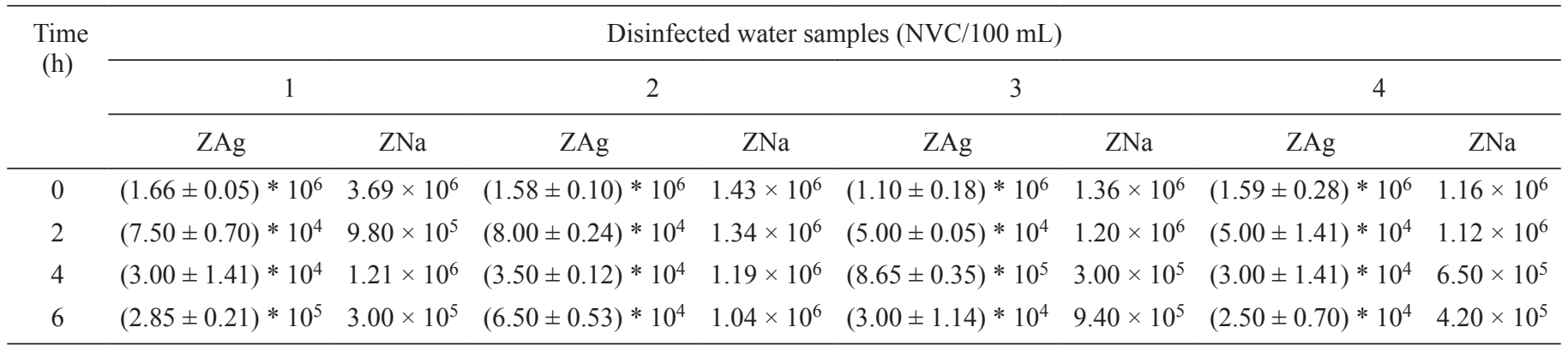

$\mathrm{NVC} / 100 \mathrm{~mL}$ is the number of viable cells per $100 \mathrm{~mL}$ of treated water; ZAg is the silver-modified natural zeolite and ZNa is the sodium-modified natural zeolite used as a reference.

Table 2. Disinfection of waste water-like (E. coli suspended in distilled water) by silver-modified natural zeolite from Sonora with a 30 mesh particle size.

\begin{tabular}{ccccccccc}
\hline \multirow{2}{*}{$\begin{array}{c}\text { Time } \\
(\mathrm{h})\end{array}$} & \multicolumn{7}{c}{ Disinfected water samples (NVC/100 mL) } \\
\cline { 2 - 9 } & \multicolumn{2}{c}{1} & \multicolumn{7}{c}{2} & & 3 & & \\
& \multicolumn{2}{c}{$\mathrm{ZAg}$} & $\mathrm{ZNa}$ & $\mathrm{ZAg}$ & $\mathrm{ZNa}$ & $\mathrm{ZAg}$ & $\mathrm{ZNa}$ & $\mathrm{ZAg}$ \\
\hline 0 & $(1.87 \pm 0.04) * 10^{6}$ & $1.93 \times 10^{6}$ & $(1.62 \pm 0.98) * 10^{6}$ & $3.02 \times 10^{6}$ & $(3.65 \pm 0.30) * 10^{6}$ & $3.65 \times 10^{6}$ & $(1.95 \pm 1.20) * 10^{6}$ & $3.65 \times 10^{6}$ \\
2 & $(3.45 \pm 0.07) * 10^{4}$ & $1.73 \times 10^{6}$ & $(3.65 \pm 0.49) * 10^{5}$ & $1.91 \times 10^{6}$ & $(3.80 \pm 0.28) * 10^{5}$ & $3.40 \times 10^{6}$ & $(4.40 \pm 0.04) * 10^{5}$ & $2.90 \times 10^{6}$ \\
4 & $(2.50 \pm 0.02) * 10^{4}$ & $5.20 \times 10^{6}$ & $(2.00 \pm 1.41) * 10^{4}$ & $6.70 \times 10^{6}$ & $(1.00 \pm 0.10) * 10^{4}$ & $2.63 \times 10^{6}$ & $(3.00 \pm 0.30) * 10^{4}$ & $6.50 \times 10^{5}$ \\
6 & $(5.00 \pm 0.50) * 10^{3}$ & $1.40 \times 10^{5}$ & $(1.50 \pm 0.10) * 10^{4}$ & $1.80 \times 10^{6}$ & $(5.00 \pm 0.05) * 10^{3}$ & $5.30 \times 10^{5}$ & $(1.50 \pm 0.20) * 10^{4}$ & $3.00 \times 10^{5}$ \\
\hline
\end{tabular}

$\mathrm{NVC} / 100 \mathrm{~mL}$ is the number of viable cells per $100 \mathrm{~mL}$ of treated water; ZAg is the silver-modified natural zeolite and ZNa is the sodium-modified natural zeolite used as a reference. 
Table 3. Disinfection of municipal wastewater (E. coli from coliform consortium) by silver-modified natural zeolite from Oaxaca with a 12 mesh particle size.

\begin{tabular}{ccccccccc}
\hline \multirow{2}{*}{$\begin{array}{c}\text { Time } \\
(\mathrm{h})\end{array}$} & \multicolumn{7}{c}{ Disinfected water samples (NVC/100 mL) } \\
\cline { 2 - 9 } & \multicolumn{2}{c}{1} & \multicolumn{7}{c}{2} & & 3 & & \\
& \multicolumn{2}{c}{$\mathrm{ZAg}$} & $\mathrm{ZNa}$ & $\mathrm{ZAg}$ & $\mathrm{ZNa}$ & $\mathrm{ZAg}$ & $\mathrm{ZNa}$ & $\mathrm{ZAg}$ \\
\hline 0 & $(5.24 \pm 0.12) * 10^{6}$ & $8.80 \times 10^{6}$ & $(3.46 \pm 0.10) * 10^{6}$ & $8.80 \times 10^{6}$ & $(9.00 \pm 1.41) * 10^{5}$ & $2.60 \times 10^{6}$ & $(1.10 \pm 0.14) * 10^{6}$ & $2.60 \times 10^{6}$ \\
\hline 2 & $(3.90 \pm 0.05) * 10^{4}$ & $8.40 \times 10^{6}$ & $(3.60 \pm 0.09) * 10^{4}$ & $8.40 \times 10^{6}$ & $(1.57 \pm 0.10) * 10^{4}$ & $1.50 \times 10^{6}$ & $(1.80 \pm 0.09) * 10^{4}$ & $1.50 \times 10^{6}$ \\
4 & $(5.65 \pm 0.35) * 10^{3}$ & $4.85 \times 10^{6}$ & $(1.50 \pm 0.42) * 10^{3}$ & $4.85 \times 10^{6}$ & $(5.25 \pm 1.73) * 10^{3}$ & $1.60 \times 10^{6}$ & $(8.50 \pm 0.56) * 10^{3}$ & $1.60 \times 10^{6}$ \\
6 & $(2.70 \pm 0.42) * 10^{3}$ & $4.05 \times 10^{6}$ & $(1.05 \pm 4.74) * 10^{3}$ & $4.05 \times 10^{6}$ & $(4.80 \pm 0.84) * 10^{3}$ & $2.20 \times 10^{6}$ & $(5.15 \pm 0.63) * 10^{3}$ & $2.20 \times 10^{6}$ \\
\hline
\end{tabular}

$\mathrm{NVC} / 100 \mathrm{~mL}$ is the number of viable cells per $100 \mathrm{~mL}$ of treated water; ZAg is the silver-modified natural zeolite and ZNa is the sodium-modified natural zeolite used as a reference.

Table 4. Disinfection of municipal wastewater (E. coli from coliform consortium) by silver-modified natural zeolite from Sonora with a 12 mesh particle size.

\begin{tabular}{|c|c|c|c|c|c|c|c|c|}
\hline \multirow{2}{*}{$\begin{array}{l}\text { Time } \\
\text { (h) }\end{array}$} & \multicolumn{8}{|c|}{ Disinfected water samples (NVC/100 mL) } \\
\hline & \multicolumn{2}{|l|}{1} & \multicolumn{2}{|l|}{2} & \multicolumn{2}{|l|}{3} & \multicolumn{2}{|l|}{4} \\
\hline 0 & $(2.82 \pm 0.12) * 10^{7}$ & $2.04 \times 10^{7}$ & $(7.25 \pm 0.35) * 10^{6}$ & $2.04 \times 10^{7}$ & $(1.08 \pm 0.11) * 10^{6}$ & $3.80 \times 10^{6}$ & $(1.68 \pm 0.24) * 10^{6}$ & $3.80 \times 10^{6}$ \\
\hline 2 & $(5.00 \pm 2.12) * 10^{3}$ & $2.04 \times 10^{7}$ & $(3.50 \pm 0.40) * 10^{5}$ & $2.30 \times 10^{7}$ & $(7.00 \pm 2.83) * 10^{4}$ & $3.75 \times 10^{6}$ & $(4.50 \pm 0.40) * 10^{4}$ & $3.75 \times 10^{6}$ \\
\hline
\end{tabular}

$\mathrm{NVC} / 100 \mathrm{~mL}$ is the number of viable cells per $100 \mathrm{~mL}$ of treated water; ZAg is the silver-modified natural zeolite and ZNa is the sodium-modified zeolite used as a reference.

the municipal wastewater. This indicates that the origin of the zeolites and their particle dimensions do not notably influence municipal wastewater disinfection. These results differ from those obtained using silver-modified natural zeolites from Oaxaca and Sonora with particle dimensions of 12, 20 and 30 mesh as disinfectant agents in wastewater-like, because the presence of certain compounds in municipal wastewater influences the water disinfection process [13]. Significant statistical differences were not found between the four independent experiments.

The bactericidal action of silver-modified clinoptiloliterich tuffs (silver-modified natural zeolites) with different particle dimensions may be due to the ability of $\mathrm{Ag}^{+}$to move out of the crystalline network of the zeolite and into aqueous media where it is taken up by microorganisms and kills them. It is important to note that both particle size and geographical origin of the silver-modified clinoptilolite-rich tuffs are expected to affect desorption of $\mathrm{Ag}^{+}$from the silver modified clinoptilolite-rich tuffs.

Significant disinfection of municipal wastewater was not observed after 6 hours using sodium-modified natural zeolite from Oaxaca or Sonora with particle sizes of 12, 20 and 30 mesh (ZONa12, ZONa20, ZONa30, ZSNa12, ZSNa20 and $\mathrm{ZSNa} 30)$. These results are similar to those observed upon disinfection of the $E$. coli suspended in distilled water (wastewater-like). It is important to note that $\mathrm{Na}^{+}$is considered an essential element for microorganisms and does not exhibit bactericidal activity.

\section{Experimental}

\section{Materials and Methods Materials}

Clinoptilolite-rich tuffs from Oaxaca and Sonora were used in this work. These materials have previously been characterized by De la Rosa [14]. The major component of both natural zeolites is clinoptilolite, and the ratio of $\mathrm{Si} / \mathrm{Al}$ is 4.46 for $\mathrm{ZS}$ and 5.47 for ZO. Zeolites were ground and sieved. Diameters of the particles selected to carry out the experiments were 12,20 and 30 mesh.

Commercial analytical grade reagents were used in this work: $\mathrm{NaCl}$ and $\mathrm{AgNO}_{3}$ (J. T. Baker), Luria Bertani and Endo broth (Bioxon), and E. coli ATCC 8739 from the American Type Culture Collection (ATCC).

\section{Modified clinoptilolite-rich tuff Sodium-modified clinoptilolite-rich tuff preparation}

Samples of each particle size (12, 20 or 30 mesh) of clinoptilolite-rich tuff were treated with $1 \mathrm{M} \mathrm{NaCl}$ at $90^{\circ} \mathrm{C}$ for a period 
of $24 \mathrm{~h}$ and then washed with deionized water until chloride ions were not detected [11]. The sample was then dried at $85^{\circ} \mathrm{C}$ for 5 hours. These samples were named ZONa12, ZONa20, $\mathrm{ZONa} 30, \mathrm{ZSNa} 12, \mathrm{ZSNa} 20$ and $\mathrm{ZSNa} 30$ where $\mathrm{Z}$ indicate a zeolite, $\mathrm{O}$ or $\mathrm{S}$ are Oaxaca or Sonora states from Mexico, Na is sodic form and 12, 20 and 30 are the corresponding particle dimensions in mesh.

\section{Silver-modified clinoptilolite-rich tuff preparation}

Samples of sodium modified clinoptilolite-rich tuffs of different particle dimensions were suspended in $0.1 \mathrm{M} \mathrm{AgNO}_{3}$ and refluxed for $12 \mathrm{~h}$ in the dark. Solid material was separated by centrifugation, washed and dried [11]. These experimental conditions yielded the highest attainable amount of silver incorporation into natural zeolites. In this case the samples were denoted as ZOAg12, ZOAg20, ZOAg30, ZSAg12, ZSAg20 and ZSAg30, where Ag is silver modified zeolites from Oaxaca or Sonora with different particle dimentions (12, 20 or 30 mesh).

\section{Municipal Wastewater Sampling}

Wastewater samples were collected from dechlorinated effluent of the municipal wastewater plant "Compañía Operadora de Ecosistemas (ECOSYS)" [17] at 9 am and samples were analyzed within $2 \mathrm{~h}$ of collection [18].

\section{Microbiological Experiments Microorganism Growth Conditions}

Escherichia coli ATCC 8739 and E.coli from wastewater were selected as indicators of fecal contamination. Luria Bertani (LB) broth was used as growth medium for E. coli, and Endo broth was used for $E$. coli and total coliform quantification.

\section{Preparation of Microorganism Suspension}

E. coli was grown aerobically in LB broth at $37^{\circ} \mathrm{C}$ for $12 \mathrm{~h}$. The cultures were washed twice and pelleted by centrifugation at 10,000 rpm. Cells were resuspended in distilled water at a final concentration of $10^{9}$ cells $/ 100 \mathrm{~mL}$.

\section{Water Disinfection Assay}

Ten milligrams of sodium or silver-modified natural Mexican zeolites $(12,20$ or 30 mesh) was added to $100 \mathrm{~mL}$ of the prepared $E$. coli suspension or municipal wastewater and aerated at $37{ }^{\circ} \mathrm{C}$ for 0 to 6 hours. Aliquots $(1 \mathrm{~mL})$ were taken from these mixtures [water + bacteria (E. coli ATCC 8739 or E.coli from wastewater) + sodium or silver modified clinoptiloliterich tuffs] at 0, 2, 4, 6 hours. Aliquots were diluted with $30 \mathrm{~mL}$ of $0.01 \mathrm{M}$ phosphate buffer and filtered through membranes with a pore size of $0.45 \mu \mathrm{m}$ according to the APHA method [19] of coliform bacteria enumeration. Membranes were incubated at $35^{\circ} \mathrm{C}$ for $24 \mathrm{~h}$. Bacterial colonies were counted with a cell counter (C-110-76887, New Brunswick Scientific). Four independent experiments of each growth assay were performed with two replicates.

\section{Acknowledgements}

The authors acknowledge financial support provided by CONACYT (Project 46219) and are grateful to Beatriz Barrientos for providing laboratory facilities.

\section{References}

1. Lu, W.; Kiene, L.; Levi, Y. Water Res. 1999, 33, 827-835.

2. Rennecker, J. L.; Corona-Vasquez, B.; Driedger, A. M.; Rubin, S. A.; Mariñas, B. J. Water Sci. Technol. 2001, 43, 167-170.

3. Hassen, A.; Mahrouk, M.; Ouzari, H.; Cherif, M.; Boudabous, A.; Damelincourt, J. J. Bioresource Technol. 2000, 74, 141-150.

4. Gujer, W.; Gounten von, U. Water Res. 2003, 37, 1667-1677.

5. Butkus, M. A.; Labare, M. P.; Starke, J. A.; Moon, K.; Talbot, M. Appl. Environ. Microb. 2004, 70, 2848-2853.

6. Koivunen, J.; Heinonen-Tanski, H. Water Res. 2005, 39, 15191526.

7. Barcelona, P. L. Documento del Registro Sanitario de la Repúplica de Cuba. Cuba, 1996.

8. Pérez, P. M. Estudio del efecto de la concentración de metales pesados soportados en zeolitas naturales en la remoción de microorganismos indicadores de contaminación, Dissertation, Universidad de la Habana, 1998.

9. Milán, Z.; De las Pozas, C.; Cruz, M.; Borja, R.; Sánchez, E.; Llangovan, K.; Espinosa, Y.; Luna, B. J. Environ. Sci. Health A 2001, 36, 1073-1087.

10. Inoue, Y.; Hoshino, M.; Takahashi, H.; Noguchi, T.; Murata, T.; Kanzaki, Y.; Hamashima, H.; Sasatsu, M. J. Inorg. Biochem. 2002, 92, 37-42.

11. Rivera-Garza, M. Propiedad Antibacteriana de la Clinoptilolita Intercambiada con Plata, frente a Escherichia coli y Streptococcus faecalis, Master thesis, Universidad Autónoma del Estado de México, 1999.

12. Burrola-Aguilar, C. Cinética del proceso de desinfección del agua al utilizar clinoptilolita natural intercambiada con iones metálicos como microbicida, Dissertation, Universidad Autónoma del Estado de México, 2004.

13. De La Rosa-Gómez, I. Evaluación del efecto bactericida de mineral zeolítico de plata sobre la carga microbiana de aguas residuales de origen municipal, Master thesis, Universidad Autónoma del Estado de México, 2002.

14. De la Rosa-Gómez, I. Comportamiento de Rocas Zeolíticas Acondicionadas con Plata, en el Proceso de Desinfección de Agua Residual de Origen Municipal, $\mathrm{PhD}$ thesis, Instituto Tecnológico de Toluca, 2007.

15. De la Rosa-Gómez, I.; Olguín, M. T.; Alcántara, D., J. Environ. Manage. 2007, 88, 853-863.

16. Rivera-Garza, M.; Olguín, M. T.; García-Sosa, I.; Alcántara, D.; Rodríguez-Fuentes, G. Silver supported on natural Mexican zeolite as an antibacterial material, Micropor. Mesopor. Mat. 2000, 39, 431-444.

17. Santana, A. Reporte de Operación de la Compañía Operadora de Ecosistemas (ECOSYS), Estado de México, 2003.

18. NMX-AA-003. Aguas Residuales, Muestreo, Dirección General de Normas, Secretaría de Comercio y Fomento Industrial, México, 1980.

19. APHA, AWWA, WPCF. Métodos Normalizados para el Análisis de Aguas Potables y Residuales. US, 1992. 